\title{
Establishing Relationship of Porosity and Strength of Fibre Reinforced Concrete
}

\author{
PL. Meyyappan, N. Ganesan
}

\begin{abstract}
There are numerous factors that affect the performance of concrete in terms of strength and durability aspects. Amongst, the pores in the concrete are the one which is playing a foremost role in deciding strength and durability characteristics. The presences of pores in the concrete are due to inferior quality of concrete ingredients, lack of $w / c$ ratio, improper compaction, poor workmanship etc. Many past studies reveal that the presence of fillers materials may reduce the pores on the concrete. But at the same time, the strength and durability should improve a lot. Under these circumstances, the presence of steel fibres in the concrete will give a better solution to arrest the pores and furnish desired results in all aspects. This study is made an attempt to establish the relationship between porosity and compressive strength on the various proportions of steel fibres of M20 and M40 grade concrete.
\end{abstract}

Keywords : Steel fibre reinforced concrete; fibre content, Compressive strength; Porosity

\section{INTRODUCTION}

$\mathrm{T}$ he past researches prescribed that the strength and durability properties of any type of concrete are affected by the numerous factors such as water-cement ratio, grade of concrete, curing conditions, quality of concrete ingredients, compaction and mixing of concrete etc. Among the all, the most important one is improper compaction and due to that, there may be a chance of voids / pores in to the concrete and that leads to an aggressive manner of strength reduction phenomenon. In order to reduce the pores on concrete, fillers can be used as indicated in many literatures. The fillers can be either minerals or fibrous materials. In order to enhance the durability as well as strength related properties, fibres can be

preferred. In this experimental study, it has been planned to establish the correlation of porosity and strength of the concrete where steel fibers are added to serve as filler materials or a void arrestors. For establishing the relationship between the porosity and strength, it is decided to conduct an experimental test of compression and water absorption on different grades (M20 grade and M40 grade) on the different proportions $(0 \%, 1 \%, 2 \%, 3 \%$ and $4 \%)$ of steel fibres.

\section{MATERIAL USED}

The concrete constituent materials used in this

Revised Manuscript Received on December 30, 2019.

* Correspondence Author

PL. Meyyappan*, Civil department, Kalasalingam Academy of Research and Education, Krishnankoil, India. Email: meyyappan@klu.ac.in N.Ganesan, Department of Civil Engineering, Kalasalingam Academy of Research and Education, Krishnankoil, Virudhunagar District, Tamilnadu . Email: civilganesan139@gmail.com experimental study were ordinary portland cement (53 grade), fine aggregate, coarse aggregate, and deformed steel fibres of aspect ratio of 45 . In order to verify the quality of cement and aggregates, they are tested in the concrete laboratory as per the standard requirements of IS:8112 and IS 383 , respectively. Deformed steel fibres having an aspect ratio of 45 ( $0.6 \mathrm{~mm}$ in diameter and $25 \mathrm{~mm}$ long) were used in this study. The water to be used for mixing the ingredients will be potable drinking water standards.

\section{EXPERIMENTAL INVESTIGATION}

By using IS 10262, the concrete mix was adopted for this experimental study is $1: 1.74: 2.45: 0.45$ and 1:1:1.52:2.28:0.45 for M20 grade and M40 grade respectively. First the dry state of mixing is prepared by mixing the constituents of cement and fine aggregate, then coarse aggregate. Then the calculated quantity of steel fibers was spread out uniformly without any bunching effect. Once the dry state of fibre reinforced concrete is ready, the calculated quantity of water as per mix design is poured slowly and wet mix is carefully prepared without any slumps, bleeding problems. The prepared fresh concrete is filled in to the respective moulds with adequate compaction. For both compression and porosity tests, cube specimens of $150 \mathrm{~mm} \mathrm{x}$ $150 \mathrm{~mm} \times 150 \mathrm{~mm}$ were casted for both the mixes. As in total, 180 cube specimens were casted for both the tests and grades against 7, 14 and 28 days of age of curing and $0 \%, 1 \%$, $2 \% 3 \%$ and $4 \%$ of volume fraction of fibres content. The compression tests were conducted in the compression testing machine of 200 tonnes capacity. The tests were performed out at a standardized stress rate of $14 \mathrm{~N} / \mathrm{mm}^{2} / \mathrm{min}$, once the specimen is kept centered in the machine. Water absorption test were conducted on the casted cube specimens to find the porosity values. The specimens were allowed to place in hot air oven in the standard temperature of 120 degree temperature. The dry weights of the specimen are to be taken before and after placing oven. It was noted as W1 and W2. The weight differences of these specimens against the initial dry weight are taken for the calculation of volume of pores to estimate the porosity. The porosity (volume of pores in percentage) can be calculated by the formula mentioned below:

$\frac{W_{1}-W_{2}}{W_{1}} \times 100$

Where, $\mathrm{W}_{1}$ - Initial weight of the specimen before oven

$\mathrm{W}_{2}$ - Final weight of the

specimen after oven 


\section{RESULT AND DISCUSSIONS}

The results of compressive strength test and water absorption test for M20 and M40 grade concrete were tabulated in Table 1 against the different percentages of steel fibers and curing days. For without steel fibers, the compression test values are $15.13 \mathrm{~N} / \mathrm{mm}^{2}, 20.18 \mathrm{~N} / \mathrm{mm}^{2}$ and $24.03 \mathrm{~N} / \mathrm{mm}^{2}$ for 7 days, 14 days and 28 days curing respectively for M20 grade concrete. In case of M40 grade concrete, the compression test values are $26.04 \mathrm{~N} / \mathrm{mm}^{2}, 35.41$ $\mathrm{N} / \mathrm{mm}^{2}$ and $40.71 \mathrm{~N} / \mathrm{mm}^{2}$ for 7 days, 14 days and 28 days curing respectively. It seems that, the strength is more for higher grades due to the increase of cement content. The compressive strength values are increased due to the increase in age of curing days. When the age of curing days are more, the rate of hydration process are almost completed. In addition of $1 \%$ of steel fibers in to the concrete, the compressive strength is increased by $12.5 \%$ and $7 \%$ for M20 and M40 grade concrete. If the steel fibers content is increased to $2 \%$, there is an increase in compression strength of $32 \%$ for M20 grade and $27 \%$ for M40 grade concrete. When the steel fibers are added further to $3 \%$, strength of the fibre concrete has strated to decrease for both the grade of concrete. The decreasing trend is continued for further increase in steel fibers (4\%) and there by around $20 \%$ reduction in the strength when compared to $2 \%$ of steel fibers as seen in Figure 1. It is seen that from Figure 2, the test values are almost to be same for $1 \%$ and $4 \%$ of steel fibers in to the concrete. By seeing that, it the addition of steel fibers can be optimum up to $2 \%$ and by further additing, it doesn't giving fruitful result, due to the non-uniform mixing of steel fibers. Therefore the test results showing an evident that, grade of concrete, age of curing and addition of steel fibers up to optimum dosage is playing a vital role in determining the strength of the concrete.

Table- I: Experimental Results

\begin{tabular}{|c|c|c|c|c|c|}
\hline \multirow[t]{2}{*}{$\begin{array}{l}\text { Volume } \\
\text { fraction of } \\
\text { fibers }\end{array}$} & \multirow[t]{2}{*}{$\begin{array}{l}\text { Age of } \\
\text { curing } \\
\text { (Days) }\end{array}$} & \multicolumn{2}{|c|}{$\begin{array}{l}\text { Compressive } \\
\text { strength } \\
\left(\mathbf{N} / \mathbf{m m}^{2}\right)\end{array}$} & \multicolumn{2}{|c|}{$\begin{array}{c}\text { Porosity } \\
(\%)\end{array}$} \\
\hline & & M20 & $M 40$ & $M 20$ & $M 40$ \\
\hline \multirow{3}{*}{$0 \%$} & 7 & 15.13 & 26.04 & 8.43 & 7.13 \\
\hline & 14 & 20.18 & 35.41 & 7.28 & 6.39 \\
\hline & 28 & 24.03 & 40.71 & 6.72 & 5.66 \\
\hline \multirow{3}{*}{$1 \%$} & 7 & 17.03 & 27.51 & 7.37 & 6.14 \\
\hline & 14 & 22.52 & 35.79 & 6.41 & 5.49 \\
\hline & 28 & 27.46 & 43.65 & 5.95 & 4.94 \\
\hline \multirow{3}{*}{$2 \%$} & 7 & 23.66 & 33.05 & 6.53 & 5.12 \\
\hline & 14 & 30.37 & 43.58 & 5.79 & 4.59 \\
\hline & 28 & 35.32 & 52.84 & 5.28 & 4.11 \\
\hline
\end{tabular}

\begin{tabular}{|c|c|c|c|c|c|}
\hline \multirow{3}{*}{$3 \%$} & 7 & 22.18 & 30.48 & 6.91 & 6.20 \\
\cline { 2 - 6 } & 14 & 29.02 & 41.13 & 5.98 & 5.52 \\
\cline { 2 - 6 } & 28 & 34.78 & 48.26 & 5.39 & 4.43 \\
\hline \multirow{3}{*}{$4 \%$} & 7 & 16.77 & 26.86 & 7.92 & 6.71 \\
\cline { 2 - 6 } & 14 & 22.92 & 35.94 & 6.91 & 5.68 \\
\cline { 2 - 6 } & 28 & 27.95 & 43.23 & 6.14 & 5.16 \\
\hline
\end{tabular}

The porosity test values are $6.72 \%, 5.95 \%, 5.28 \%$ for M20 grade concrete and $5.66 \%, 4.94 \%, 4.11 \%$ for M40 grade concrete against $0 \%, 1 \%$ and $2 \%$ of addition of steel fibers respectively. Generally by the presence of rich mix, the volume of pores reduced. This is happening because the fine cement particles occuying the pores. In figure 3 , it is observed that, the volume of pores are getting reduced when percentage of steel fibers are increased upto $2 \%$. By the presense of $2 \%$ of volume fraction of steel fibers $22 \%$ of pores are arrested for M20 grade and $27 \%$ of pores for M40 grade concrete. When the steel fibers are increased beyond 2 $\%$, the pores are getting increased due to the non-uniform disperse of steel fibres. From Table 1, it is also seen that, by increase in the age of curing days, the volume of pores are getting reduced due to the occupancy of hydration products in to the pores.

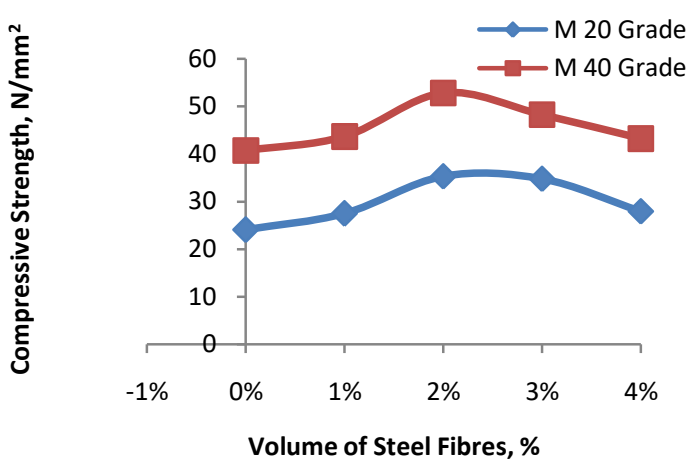

Fig. 1.Compressive Strength Vs Steel Fibers for both grades

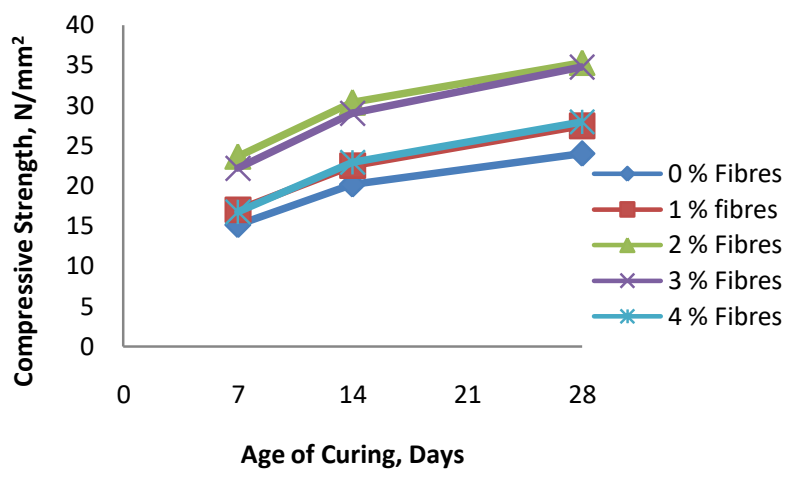

Fig. 2.Compressive strength Vs Age of curing for M20 concrete 


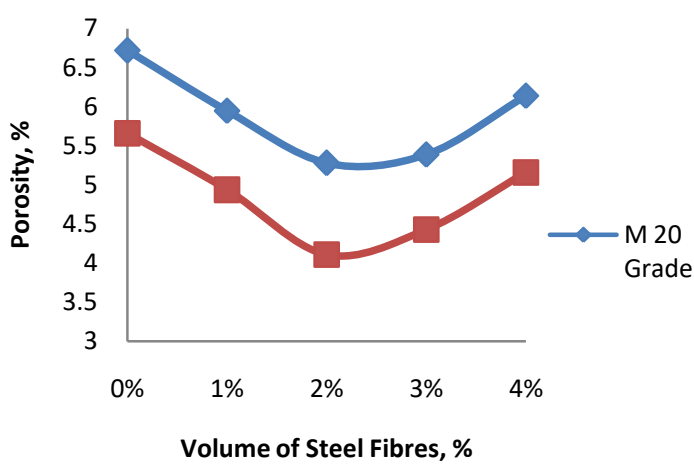

Fig. 3.Porosity Vs Steel fibers for both grades

Based on the experimental results, regression analysis is carried out to estabilish the relationship between porosity and compressive strength for M20 and M40 grades of fibre reinforced concrete. Based on Figure 4 and 5, it is understood that the volume of pores is directly affecting the strength of the factor for both the grades. For the range of 5\% to $6 \%$ pores, the strength reduction is estimated as $18 \%$ for M20 grade $10 \%$ for M40 grade. For pores in the range of $6 \%$ to 7 $\%$, the strength is further reduced to around $30 \%$ to $35 \%$ and when the pores ranges is around $7 \%$ to $8 \%$, the strength is drastically reduced to 50 to $55 \%$ for both the grades of fibre reinforced concrete. The presence of steel fibres enhancing the reduction of pores and thereby the strength of the concrete getting increased.

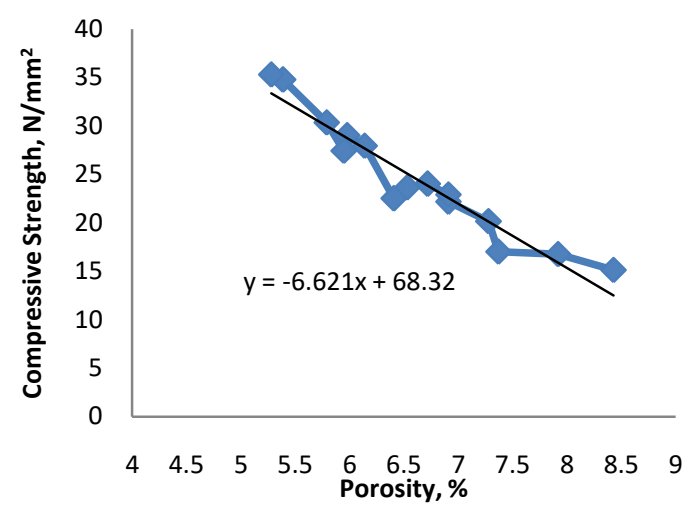

Fig. 4. Relation between Porosity Vs Compressive Strength for M20

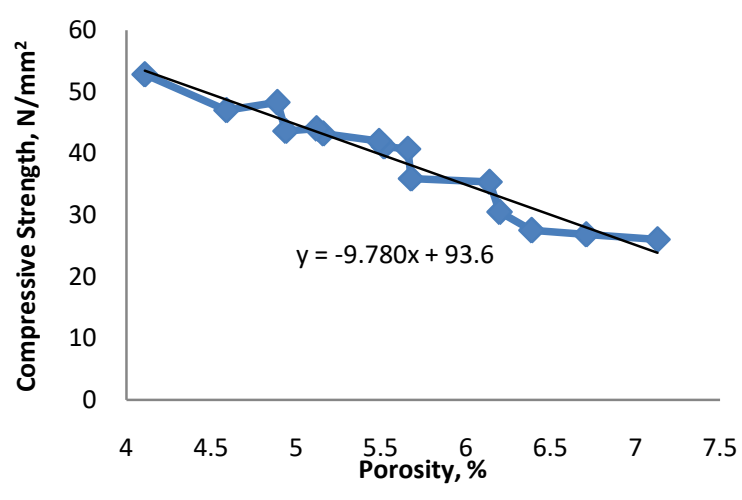

Fig. 5.Relation between Porosity Vs Compresive Strength for M40
The best-fit equation 1 and 2 is obtained for M20 and M40 grade concrete for estimating the compression strength of the fibre reinforced concrete, once the volume of pores are known.

$C S=-6.621 P+68.32$

$C S=-9.784 P+93.67$

Where, $\mathrm{CS}=$ Compressive Strength of the FRC in N/mm ${ }^{2}$

$$
\begin{aligned}
& \mathrm{P}=\text { Porosity in } \% \\
& \mathrm{~S}_{\mathrm{f}}=\text { Volume fraction of steel fibers in percentage }
\end{aligned}
$$

It is clearly understood that the experimental values and and regression values of compression strength are estabilished and well correlated in the range of plus or minus 25 .

\section{CONCLUSIONS}

1) Addition of steel fibers into concrete and rich mixes resulted in enhancement of compressive strength and significant decrease in porosity due to seizing of pores by the fibres.

2) The decrease in volume of pores with the addition of steel fibers continued with increase in volume of fraction of fibers up to $2 \%$.

3) After $2 \%$, the compressive strength is reduced along with increase in porosity values.

4) The porosity of steel fiber reinforced concrete as well as plain cement concrete decreased with increase in the age of curing.

5) Theoretical equations have been developed for compressive strength in terms of, porosity and the theoretical values were found to be well correlate in with the arrived experimental test results.

\section{REFERENCES}

1. EI-Dieb A.S and Hooton R.D. (1995) "Water-permeabilitymeasurement of high performance concrete using a high-pressure triaxial cell". Journal of Cement and ConcreteResearch, Vol.25, No.6, pp.1199-1208.

2. O. Deo, M. Sumanasooriya, and N. Neithalath, "Permeability reduction in pervious concretes due to clogging: experiments and modeling," Journal of Materials in Civil Engineering, vol. 22, no. 7, pp. 741-751, 2010.

3. M. Sonebi and M. T. Bassuoni, "Investigating the effect of mixture design parameters on pervious concrete by statistical modelling," Construction and Building Materials, vol. 38, pp. 147-154, 2013.

4. IS 516-1959 (1959). "Methods of tests for strength of concrete".Bureau of Indian Standards.

5. IS 3085-1965 (1965). "Method of test for permeability ofcement mortar and concrete". Bureau of Indian Standards.

6. Khan M.I. and Lynsdale C.J. (2002). "Strength, permeability,and carbonation of high-performance concrete". Journal ofCement and Concrete Research, 32 (2002), 123131.

7. Miloud B. (2005). "Permeability and porosity characteristics ofsteel fiber reinforced concrete." ASIAN JOURNAL OF CIVILENGINEERING (BUILDING AND HOUSING), Vol. 6, No.4, pp.317-330 
8. PL. Meyyappan, K.Kumaran, M.Gopalakrishnan and E. Harikrishnan (2018), "Effect of glass fibers, flyash and quarry ash on Strength and Durability Aspects of Concrete - An Experimental Study", IOP Conference Series: Material Science and Engineering, doi:10.1088/1757-899X/396/1/012001.

9. PL. Meyyappan, K.Kumaran, M.Gopalakrishnan and E. Harikrishnan (2018), "Experimental Investigation on the Effect of Silica fume and Pumice stone in Developing Light Weight Concrete", IOP Conference Series: Material Science and Engineering, doi:10.1088/1757-899X/561/1/012064.

10. PL. Meyyappan, P. Amuthakannan, R. Sutharsan and M. Ahamed Azik Ali (2019), "Utilization of M-Sand \& Basalt Fiber in Concrete: An Experimental Study on Strength and Durability Properties", IOP Conference Series: Material Science and Engineering, doi:10.1088/1757-899X/561/1/012035.

\section{AUTHORS PROFILE}

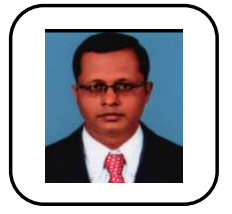

Dr. PL. Meyyappan has completed his graduation and post-graduation from Bharathiyar University and Karunya University respectively. He completed his $\mathrm{PhD}$ from Kalasalingam University. He has 13 years of teaching experience. He has completed 2 sponsored research projects from TNSCST and published more than 25 papers in peer reviewed journals and conferences. He is a life member in ISTE, IEI, IGS, ISET, ISRS. He is serving as Editorial Board Member and Reviewer in various reputed Journals.

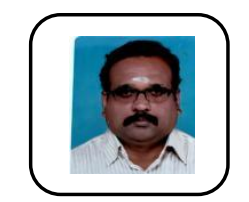

Ganesan Nagalingam completed his UG in Civil Engg. from A.C.Tech, Karaikudi and PG in Structural Engineering from Annamalai University, and pursuing his $\mathrm{PhD}$ from Kalasalingam Academy of Research and Education. He has more than twenty five years of experience in teaching and industry. His areas of research include geopolymer concrete, high performance concrete etc. 